\title{
EXPERIMENTAL STUDY OF STRENGTH AND DURABILITY OF CONCRETE WITH SODIUM SILICATE AS SURFACE TREATMENT WITH RESPECT TO FLY ASH
}

\author{
Sreenivasa Prasad Joshi ${ }^{1}$, Anand Vishnuvardhan ${ }^{2}$, M.Chaitanya ${ }^{3}$ \\ ${ }^{1}$ Assistant professor, Civil Engineering, Aurora Engineering College, Bhongir, Telengana, India \\ ${ }^{2}$ Manager M/S Bureau Veritas India $(P)$ Ltd, Hyderabad, Telangana, India \\ ${ }^{3}$ Engineer, M/S Bureau Veritas India $(P)$ Ltd, Hyderabad, Telangana, India
}

\begin{abstract}
With the increase in demand for the performance of the material, it is essential to have binder which is reasonably priced, environmental friendly and allow better process efficiency. With respect to the same, Sodium silicate based formulations have been used for increased efficiency.

The paper presents the work carried out for the improvement of mechanical properties of fly ash by adding a binder sodium silicate. Sodium silicate is added as a binder with cement and fly ash and then compacted. .The compacts were treated in normal water at room temperature for 3 days, 7 days and 28 days. The compressive strength, flexure strength were investigated.

Sodium Silicate as surface treatment is also investigated by keeping at compacts in room temperature and curing is done under special condition. Lastly beneficial for protecting from chloride attack is also investigated.

It was observed that compressive strength of fly ash increased with curing of sodium silicate and particles were dispersed and deviated from their globular equi axed shaped to multifaceted type.
\end{abstract}

Key Words: Binder, Sodium Silicate, Fly ash, Chloride attack, equi axed shaped, multifaceted type

\section{INTRODUCTION}

The structures built across the coastal areas is less durable because of corrosion. Corrosion takes place because of the chloride ions.

The presence of the chloride ions in concrete takes place in two ways:

a) From the pure components of concrete, such as water, aggregate, and cement.

b) The intrusion of chloride ions from atmosphere.

In the case of structures that are exposed to marine environments, the chloride ions directly penetrate from the sea water or by sea salt particles, where as in non marine environments, penetration caused by winter deicing salt is the primary path. The majority of cases in which there is impact on the durability life of reinforced concrete involve chloride intrusion from the external environment. Nagtaki et al. found that the risk of chloride penetration from the outside is two or three times higher than that from internal chloride. This is due to the formation of Friedel salt that the chloride anions in cementitious composites react with monosulfate $\left(\mathrm{C}_{3} \mathrm{~A} .3 \mathrm{CaSO}_{4} .12 \mathrm{H}_{2} \mathrm{O}\right)$ and replace sulfate ions. The other reason is that, after concrete is cured, the chloride penetration from the outside is hard to resolve.

In general, measures designed to suppress corrosion due to salt damage in reinforced concrete structures can be divided into three types. i) The use of a primary barrier by the coating of the concrete surface

ii) Barriers may be used in which the chloride ions are bound by the physical method of increasing the density of concrete itself.

iii) Barrier involving the formation of passive film itself on the surface of rebar.

In the present paper, the first two methods are adopted.

\section{EXPERIMENTAL PROGRAM}

The experimental program can be identified in four stages.

1. First to develop M35 grade concrete, which satisfy the properties as per IS code Specifications.

2. Second to develop M35 grade concrete with flyash (taking $30 \%$ of flyash ) which satisfy the properties as per IS code specifications.

3. Third to develop M35 grade concrete with flyash by mixing sodium silicate( $5 \%$ of wt.fraction) as binder .

4. Fourth to develop M35 grade concrete with flyash by adding sodium silicate as surface treatment.

To study the influence of mechanical properties such as compressive strength, cylinder test and flexural strength of concrete.

The experimental program consisted of arriving at suitable mix proportions that satisfied the IS Code specifications. Standard cubes of dimensions $150 \mathrm{~mm}$ x $150 \mathrm{~mm}$ x $150 \mathrm{~mm}$ 
were casted to check whether the target compressive strength is achieved for 3 days, 7-days and 28-days curing. If either the fresh properties or the strength properties are not satisfied, the mix is modified accordingly. Standard cube moulds of $(150 \times 150 \times 150 \mathrm{~mm})$ made of cast iron were used for casting standard cubes. The standards moulds were fitted such that there are no gaps between the plates of the moulds. If there small gaps they were fitted with plaster of paris. The moulds then oiled and kept ready for casting. Once the casting is kept for 24 hours, the specimens are demoulded and immersed in curing tank for requisite period.

\section{Materials Used}

The different materials used in this work are

- 53 Grade Ultra Tech ordinary Portland Cement

- Fine Aggregate

- Coarse Aggregat

- Fly ash

- Anhydrous Sodium silicate

- Water

This program consists of casting and testing of total 108 specimens. The specimens of standard cubes $(150 \mathrm{~mm} \mathrm{x}$ $150 \mathrm{~mm} \times 150 \mathrm{~mm})$, standard cylinders of $(150 \mathrm{~mm}$ dia $\mathrm{x}$ $300 \mathrm{~mm}$ height) and standard prisms of $(150 \mathrm{~mm} \times 150 \mathrm{~mm} \mathrm{x}$ $700 \mathrm{~mm}$ ) were casted for 3,7 and 28 days for compressive strength, cylinder test and flexural strength of concrete. Additional 3 cubes were used for carbonation test.

The following preliminary tests were conducted

- Sieve analysis of coarse aggregate and fine aggregate

- Specific gravity of coarse aggregate, fine aggregate and cement

- Bulk density of coarse aggregate and fine aggregate

Mix design proportions

\subsection{Preliminary Test}

\begin{tabular}{|c||c||}
\hline \multicolumn{1}{|c||}{ Preliminary test } & Result \\
\hline Sieve analysis of CA & F.M=7.17 \\
\hline Sieve analysis of FA & 2.71 \\
\hline Specific gravity of CA & 2.46 \\
\hline Specific gravity of FA & 0.40 \\
\hline Water Absorption of CA & 1.52 \\
\hline Water Absorption of FA & $1.55 \mathrm{~kg} / \mathrm{ltr}$ \\
\hline Bulk density of CA & $1.61 \mathrm{~kg} / \mathrm{ltr}$ \\
\hline Bulk density of FA & 48.35 \\
\hline Percentage of Voids of CA & 42.02 \\
\hline Percentage of Voids of FA & \\
\hline
\end{tabular}

\section{Concrete Mix Design}

Consolidated Report

\begin{tabular}{|c|c|c|c|c|c|}
\hline $\begin{array}{c}\text { Trial } \\
\text { No }\end{array}$ & $\begin{array}{c}\text { Quantity } \\
\text { of } \\
\text { Cement }\end{array}$ & $\begin{array}{c}\text { W/C } \\
\text { Ratio }\end{array}$ & $\begin{array}{c}\text { Quantity } \\
\text { of } \\
\text { Water }\end{array}$ & $\begin{array}{c}\text { Mix } \\
\text { Design } \\
\text { proportion }\end{array}$ & Result \\
\hline 1 & 400 & 0.4 & 160 & $1: 1.93: 2.77$ & $\begin{array}{c}\text { Not } \\
\text { satisfactory }\end{array}$ \\
\hline 2 & 400 & 0.41 & 164 & $1: 1.92: 2.76$ & $\begin{array}{c}\text { Not } \\
\text { satisfactory }\end{array}$ \\
\hline 3 & 400 & 0.42 & 168 & $1: 1.91: 2.74$ & $\begin{array}{c}\text { Not } \\
\text { satisfactory }\end{array}$ \\
\hline 4 & 400 & 0.43 & 172 & $1: 1.90: 2.73$ & $\begin{array}{c}\text { Not } \\
\text { satisfactory }\end{array}$ \\
\hline 5 & 400 & 0.44 & 176 & $1: 1.89: 2.71$ & $\begin{array}{c}\text { Not } \\
\text { satisfactory }\end{array}$ \\
\hline 6 & 380 & 0.45 & 171 & $1: 2.02: 2.90$ & $\begin{array}{c}\text { Not } \\
\text { satisfactory }\end{array}$ \\
\hline $\mathbf{7}$ & $\mathbf{3 8 0}$ & $\mathbf{0 . 4 4}$ & $\mathbf{1 6 7 . 2}$ & $\mathbf{1 : 1 . 9 8 : 2 . 8 4}$ & Satisfactory \\
\hline
\end{tabular}

\section{Mix design with Fly ash}

Ratio of Mix Proportion :1: 1.65:2.68

Result:True Slump Achieved

\section{Mix design with Fly ash and Sodium Silicate}

Ratio of Mix Proportion :1: 1.65:2.68

Result:True Slump Achieved

\section{Consolidated Report}

\section{Cubical Test}

\begin{tabular}{|c|c|c|c|c|}
\hline $\begin{array}{c}\text { Number } \\
\text { of } \\
\text { Days }\end{array}$ & M35 & $\begin{array}{c}\text { M35+ } \\
\text { Flyash }\end{array}$ & $\begin{array}{c}\text { M35+Flyash+ } \\
\text { SodiumSilicate }\end{array}$ & $\begin{array}{c}\text { M35+Flyash+ } \\
\text { SodiumSilicate } \\
\text { Curing }\end{array}$ \\
\hline 3 & 28.85 & 17.17 & 7.36 & 16.55 \\
\hline 7 & 40.49 & 23.76 & 12.50 & 26.6 \\
\hline 28 & 53.88 & 34.48 & 18.50 & 38.0 \\
\hline
\end{tabular}

\section{Cylinder Test}

\begin{tabular}{|c|c|c|c|c|}
\hline $\begin{array}{c}\text { Number } \\
\text { of } \\
\text { Days }\end{array}$ & M35 & $\begin{array}{c}\text { M35+ } \\
\text { Flyash }\end{array}$ & $\begin{array}{c}\text { M35+Flyash+ } \\
\text { SodiumSilicate }\end{array}$ & $\begin{array}{c}\text { M35+Flyash+ } \\
\text { SodiumSilicate } \\
\text { Curing }\end{array}$ \\
\hline 3 & 16.08 & 8.91 & 4.13 & 9.30 \\
\hline 7 & 17.17 & 17.17 & 6.34 & 17.58 \\
\hline 28 & 25.00 & 21.45 & 8.49 & 34.20 \\
\hline
\end{tabular}




\section{Flexure Test}

\begin{tabular}{|c|c|c|c|c|}
\hline $\begin{array}{c}\text { Number } \\
\text { of } \\
\text { Days }\end{array}$ & M35 & $\begin{array}{c}\text { M35+ } \\
\text { Flyash }\end{array}$ & $\begin{array}{c}\text { M35+Flyash+ } \\
\text { SodiumSilicate }\end{array}$ & $\begin{array}{c}\text { M35+Flyash+ } \\
\text { SodiumSilicate } \\
\text { Curing }\end{array}$ \\
\hline 3 & 1.24 & 0.56 & 0.53 & 0.71 \\
\hline 7 & 1.49 & 1.22 & 0.78 & 1.23 \\
\hline 28 & 1.68 & 1.63 & 1.60 & 1.73 \\
\hline
\end{tabular}

Graphical Representation of Compressive Strength $\underline{3 \text { days }}$

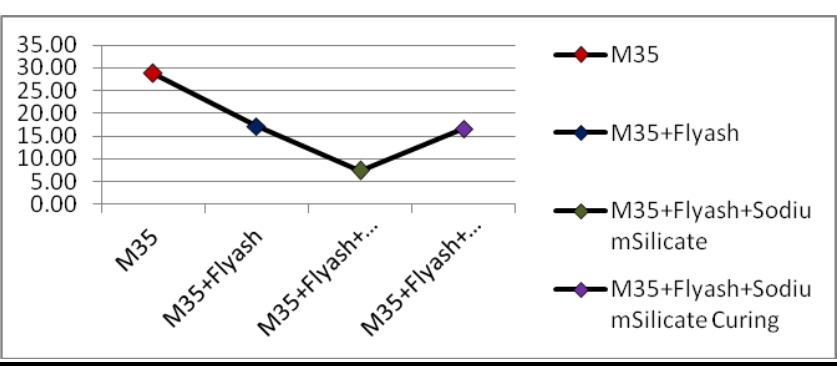

\section{7 days}

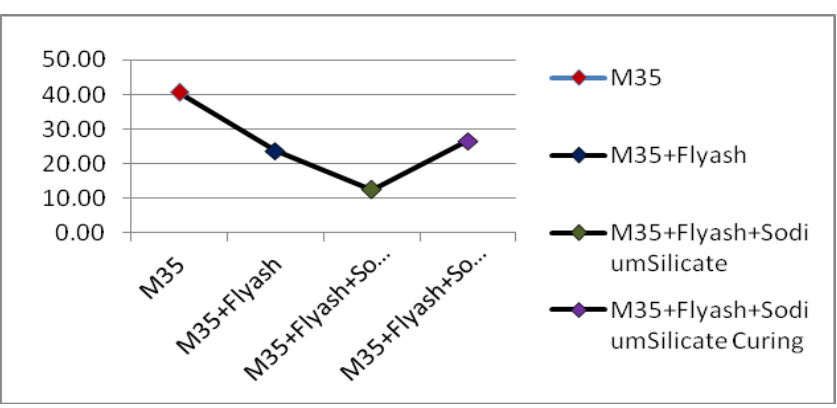

\section{$\underline{28 \text { days }}$}

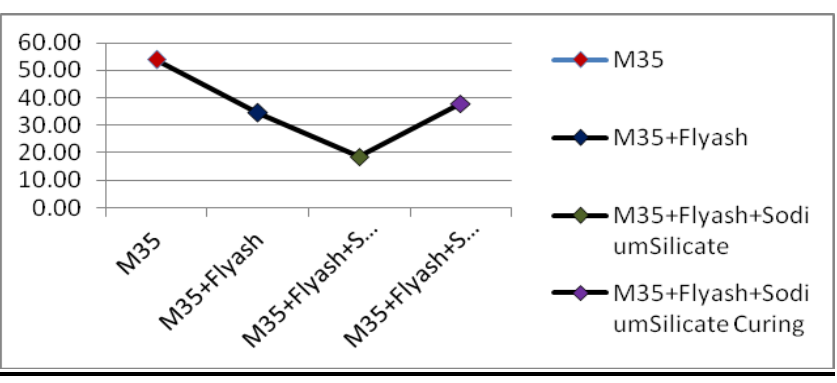

\section{Graphical Representation of Cylinder Test}

\section{$\underline{3 \text { days }}$}

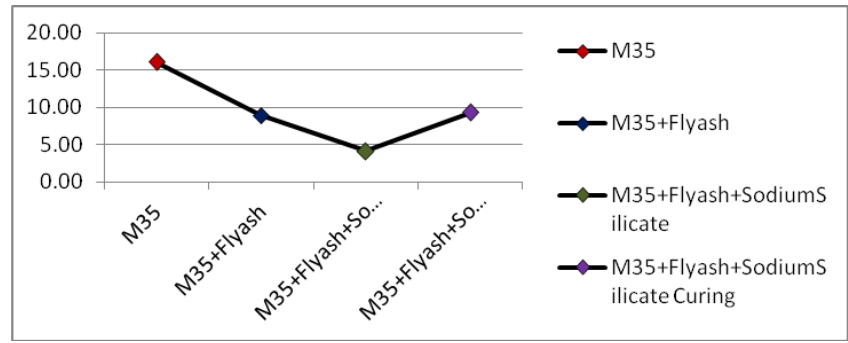

\section{7 days}

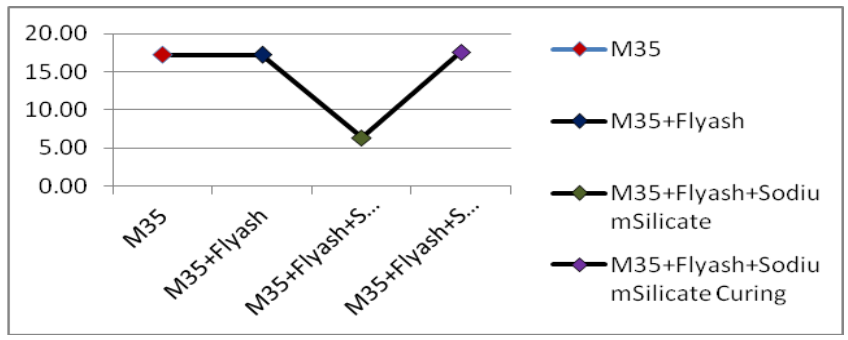

\section{8 days}

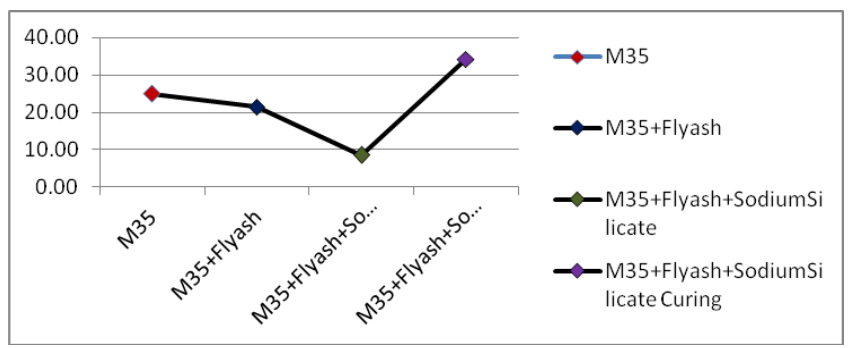

\section{Graphical Representation of Flexure Strength}

$\underline{3 \text { days }}$

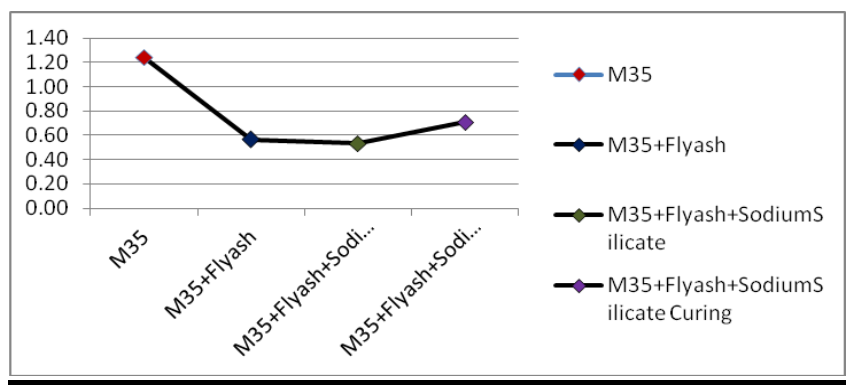

\section{7 days}

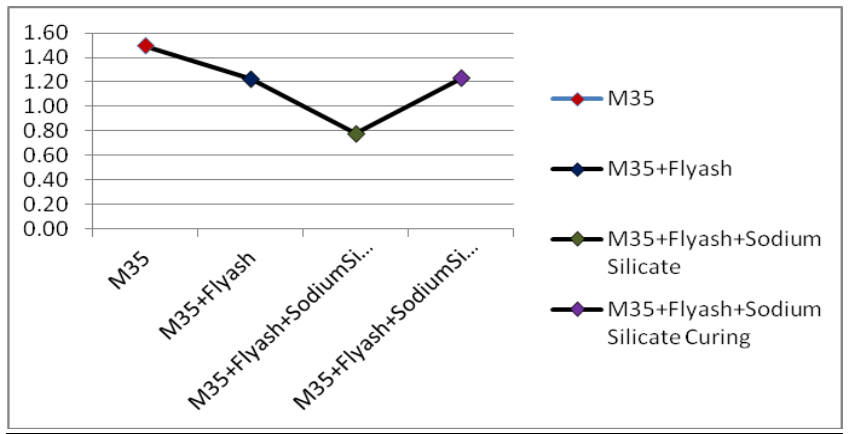




\section{8 days}

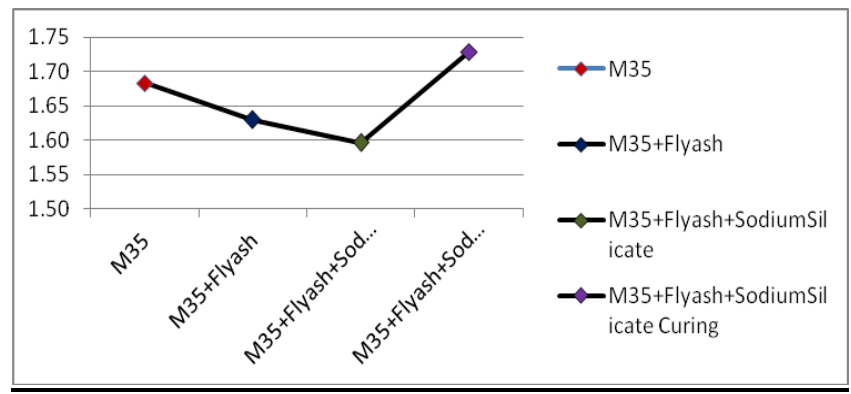

\section{CARBONATION}
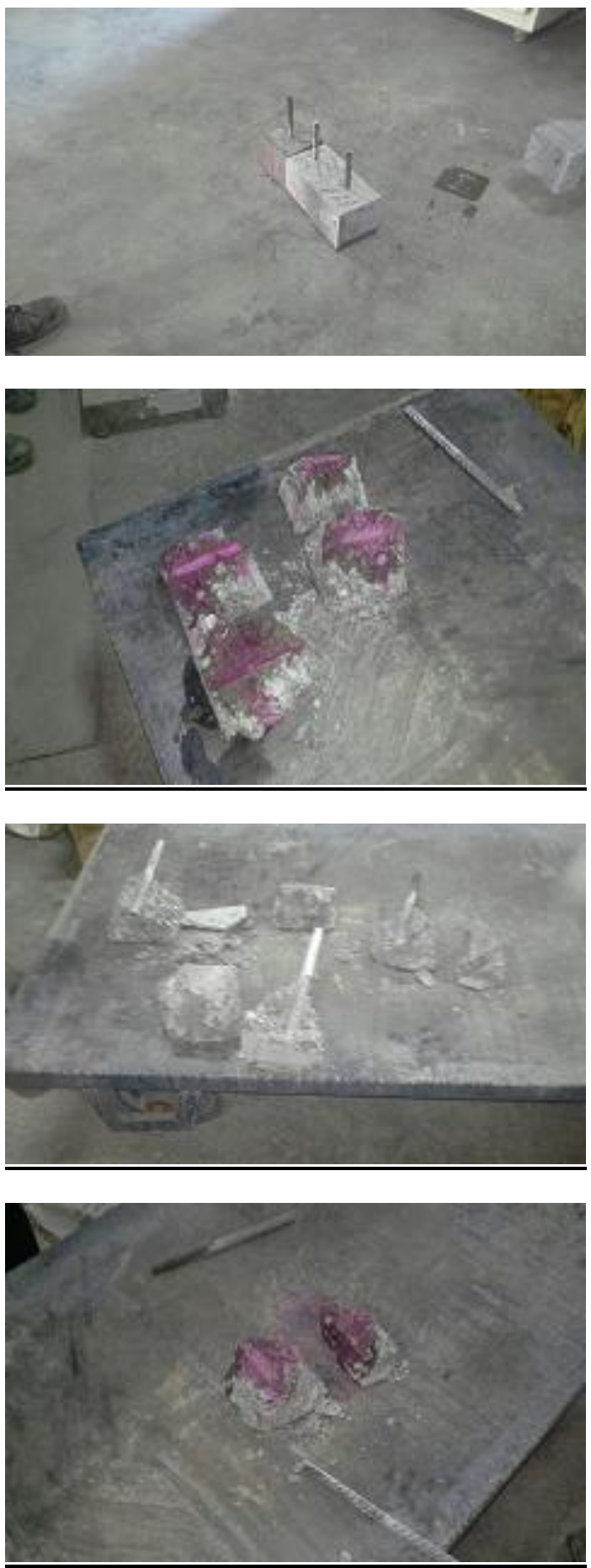

\section{CONCLUSIONS}

In order to increase resistance to the external chloride penetration of concrete structures in saline environments, sodium silicate as mixing and sodium silicate as surface treatment were used along with partial replacement of cement and fly ash.

The following discussions can be drawn from the 3 experiments tested in this study

1) Results were not satisfactory, when the concrete is mixed with sodium silicate $(5 \%)$. In every case the results were below par with the results of normal concrete and concrete with flyash. The reason could be attributed improper bonding of silicates with concrete and sufficient green bond strength was not achieved. The other reason could be amount of sodium silicate inclusion could be small.

2) Sodium silicate when used as surface treatment, at the early age results were similar to that with concrete mixing with fly ash. But as the age goes on increasing, there was increase in strength when compared fly ash mixing with normal concrete.The reason could be attributed to

a) Reduction of chloride diffusion coefficient

b) Reduction of immersion of water absorbtion of concrete

3) For durability assessment, carbonation test was conducted. It shows a particular significant change according to the mixed amount of OPC in the binder.

Pink colour indicates carbonation is done to a lesser extent because of the prensence of $\mathrm{Ca}(\mathrm{OH})_{2}$.

Carbonation resistance was superior in sodium silicate as surface treatment when compared to other three mix proportions.

From the above discussion it can be concluded that

- sodium silicate in freshly mixed portland cement has the effect of raising the $\mathrm{pH}$ of the pore fluids as well as maintaining a elevated level of silicon ions in these fluids.

- In cement fly ash and dust based stabilization systems, the gelling time can be controlled from half minute to half an hour, instead of $24-48$ hours.

- Sodium silicate as surface coating can extend the service life significantly, if exposed to chloride contaminated solutions. But care should be taken that, the attack is not from the external factors, which directly affects the covering property.

\section{SCOPE OF STUDY}

- Discussion related to silica fume as admixture can be studied

- Discussion with respect to different temperature can be studied

- Comparision with other binding materials like polyuretehne coating, silane/siloxane can be studied.

- Comparision with other chemicals like linseed oil, turpentine oil can be studied. 

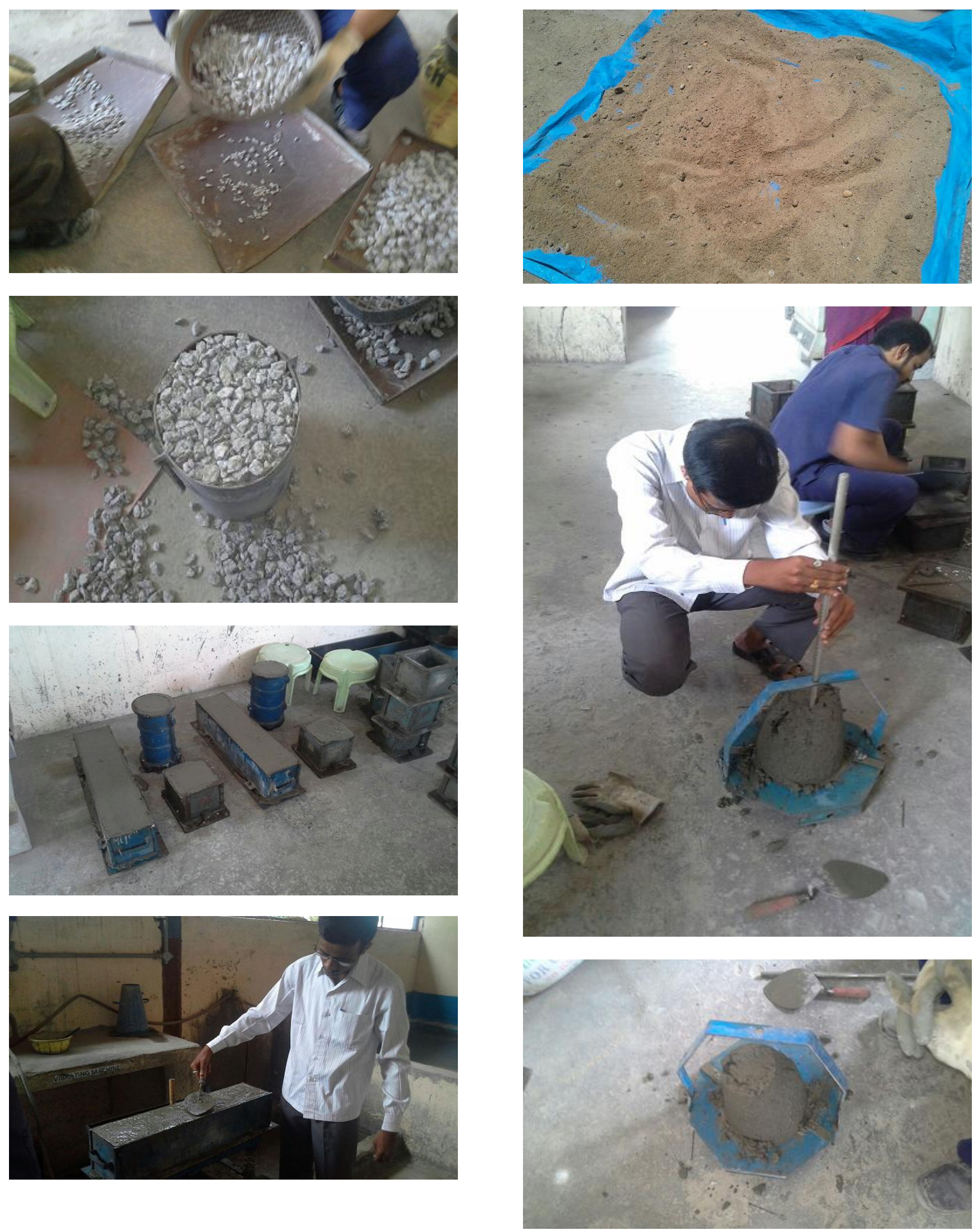

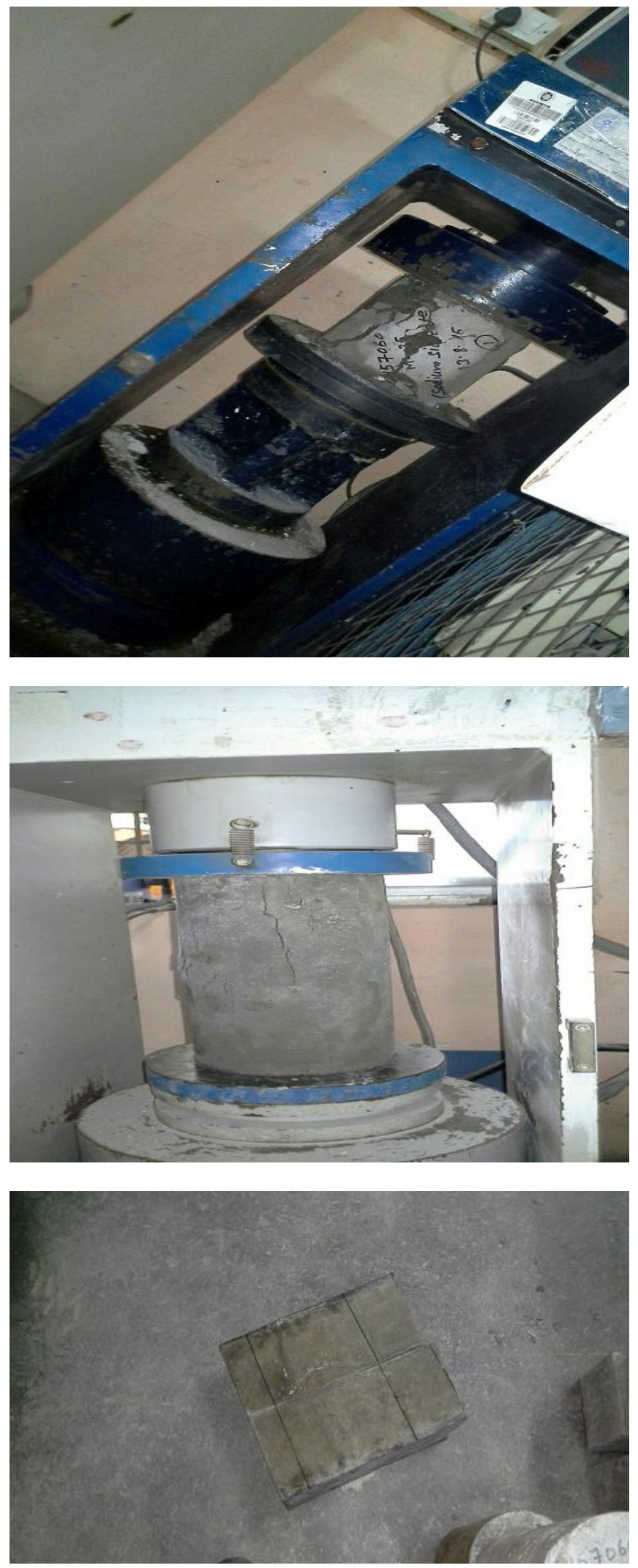
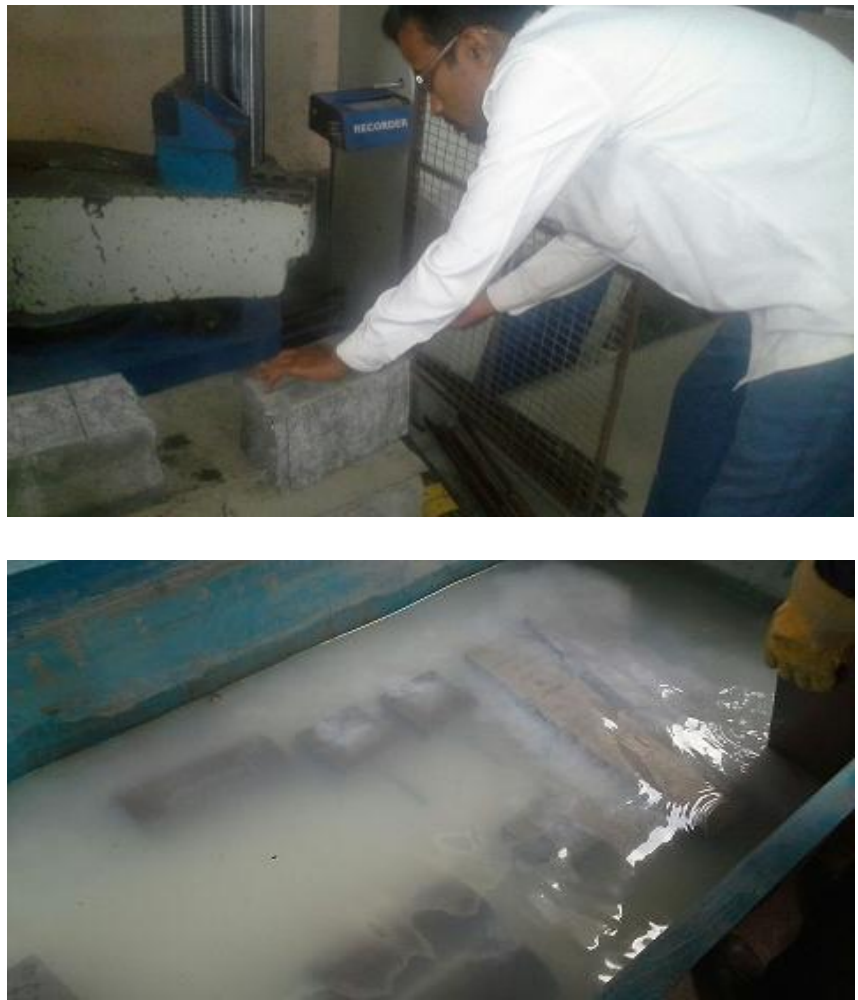

Surface Treatment with Sodium Silicate

\section{BIBILOGRAPHY}

[1] 'Concrete Technolgy Theory and Practice' - M.S.Shetty

[2] IS 456(2000) - Plain and Reinforced Concrete-Code of Practice

[3] IS 383(1970) - Specifications for Coarse and Fine Aggregate From Natural Sources for Concrete

[4] IS 10262(2009) - Guide Lines for concrete mix design proportioning

[5] IS 3812(Part 1) : 2013 - Specification for Pulverized Fuel Ash, Part 1: For Use as Pozzolana in Cement, Cement Mortar and Concrete

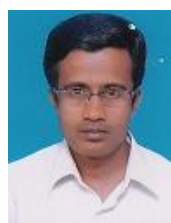

\section{Mr. Sreenivasa Prasad Joshi}

Assistant Professor

Aurora Engineering College, Bhongir.

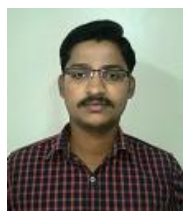

Mr. Anand Vishnuvardhan

Manager-Quality Control,

$\mathrm{M} / \mathrm{s}$ Bureau Veritas, India

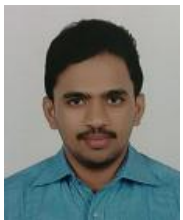

Mr. M.Chaitanya,

Engineer,

M/s Bureau Veritas, India 